\title{
Orthopaedic Implant-Related Sarcoma: A Study of Twelve Cases
}

\author{
Suzanne B. Keel, M.D., Kenneth A. Jaffe, M.D., G. Petur Nielsen, M.D., Andrew E. Rosenberg, M.D. \\ The James Homer Wright Pathology Laboratories (SBK, GPN, AER), Massachusetts General Hospital, \\ Harvard Medical School, Boston, Massachusetts; and the Department of Orthopaedic Surgery (KAJ), \\ University of Alabama Medical Center, Birmingham, Alabama
}

Sarcoma developing in association with a metallic orthopaedic prosthesis or hardware is an uncommon, but well recognized complication. We review 12 cases of sarcomas arising in bone or soft tissue at the site of orthopaedic hardware or a prosthetic joint. Nine patients were male, and three were female. Their ages ranged from 18 to 85 (mean 55) years at the time of diagnosis of the malignancy. Five patients had undergone hip arthroplasty for degenerative joint disease, four had been treated with intramedullary nail placement for fracture, two had staples placed for fixation of osteotomy, and one had hardware placed for fracture fixation followed years later by a hip arthroplasty. The time interval between the placement of hardware and diagnosis of sarcoma was known in 11 cases and ranged from 2.5 to 33 (mean 11) years. The patients presented with pain, swelling, or loosening of hardware and were found to have a destructive bone or soft tissue mass on radiography. Two sarcomas were located primarily in the soft tissue and 10 in bone. Seven patients developed osteosarcoma, four malignant fibrous histiocytoma, and one a malignant peripheral nerve sheath tumor. All sarcomas were high grade. Three patients had metastatic disease at the time of diagnosis. Follow-up was available on eight patients: five patients died of disease 2 months to 8 years (mean 26 months) after diagnosis; two patients died without evidence of disease 7 and 30 months after diagnosis; and one patient is alive and free of disease 8 years after diagnosis. Sarcomas that occur adjacent to orthopaedic prostheses or hardware are of varied types, but are usually osteosarcoma or malignant fibrous histiocytoma. They behave aggressively and frequently metastasize. Clinically, they should be distinguished

Copyright $(2) 2001$ by The United States and Canadian Academy of Pathology, Inc.

VOL. 14, NO. 10, P. 969, 2001 Printed in the U.S.A.

Date of acceptance: June 27, 2001.

Address reprint requests to: Andrew E. Rosenberg, M.D., Department of Pathology, Massachusetts General Hospital, 32 Fruit Street, Boston, MA 02114; e-mail: arosenberg@partners.org. from non-neoplastic reactions associated with implants, such as infection and a reaction to prosthetic wear debris.

KEY WORDS: Prosthetic implant, Sarcoma. Mod Pathol 2001;14(10):969-977

Metallic orthopaedic hardware and prosthetic joints have been used for decades to repair skeletal defects and replace poorly functioning or severely painful joints. Over 140,000 total hip arthroplasties, 103,000 revisions, and 30,000 partial hip replacements were performed in the United States in 1996 ( $0.7 \%$ of the U.S. population) (1) and metallic hardware is routinely used for fracture fixation as well as other orthopaedic procedures. The biomaterials used in these devices are generally considered to be nontoxic; however, some of the constituents have been shown to be potentially carcinogenic in laboratory animal studies (2-7) and malignancies have been associated with orthopaedic implants in pets (8). In humans the development of an orthopaedic implant associated malignancy is a rare, but well recognized complication. Thirty-one case reports of implant-related sarcoma (9-37) and two cases of implant-related lymphoma are present in the English language literature $(38,39)$. The literature describing this phenomenon has stressed the clinical aspects of the cases or the metallic composition of the implants that have the highest association with malignant transformation; however, none has focused on the pathology of orthopaedic implantrelated sarcoma. Herein, we present the clinical aspects and review in detail the pathologic findings of 12 implant-associated sarcomas.

\section{MATERIALS AND METHODS}

The patients were treated at the authors institutions or their slides were reviewed in consultation by some of the authors. Between 1 and 45 hematoxylin and eosin stained slides were available for review on each case. Electron microscopy was per- 
TABLE 1. Clinical Data on Patients with Implant-Related Sarcomas

\begin{tabular}{|c|c|c|c|c|c|}
\hline Case & Age/Sex & Procedure & Diagnosis & Time Interval & Symptoms and Radiographs \\
\hline 1 & $73 / \mathrm{F}$ & R THR for OA & Osteosarcoma & 2.5 years & Pain \\
\hline 2 & $18 / \mathrm{M}$ & $\begin{array}{l}\text { B femoral osteotomies, } \\
\text { staples }\end{array}$ & Osteosarcoma & 10 years & $\begin{array}{l}\text { Pain, swelling, fall with } \\
\text { pathologic fracture, osteolytic } \\
\text { lesion with periosteal new } \\
\text { bone formation }\end{array}$ \\
\hline 3 & $50 / \mathrm{M}$ & $\begin{array}{l}\text { R femur fracture with } \\
\text { fixation, R THR }\end{array}$ & $\mathrm{MFH}$ & $\begin{array}{l}2.5 \text { year THR, } \\
33 \text { years fx } \\
\text { fixation }\end{array}$ & $\begin{array}{l}\text { Pain in thigh, diagnosed as } \\
\text { infection on biopsy }\end{array}$ \\
\hline 4 & $85 / \mathrm{M}$ & L THR for OA & MPNST & 7 years & Pain $\times 4$ weeks \\
\hline 5 & $16 / F$ & $\mathrm{R}$ femur staples & Osteosarcoma & Unavailable & Unknown \\
\hline 6 & $75 / \mathrm{M}$ & R THR for OA & $\mathrm{MFH}$ & 5 years & Unknown \\
\hline 7 & $54 / \mathrm{M}$ & $\begin{array}{l}\text { Intramedullary nail for } \\
\text { fracture (stainless } \\
\text { steel) }\end{array}$ & MFH & 14 years & $\begin{array}{l}\text { Pain, tenderness, destructive } \\
\text { diaphyseal mass with cortical } \\
\text { breakthrough and periosteal } \\
\text { new bone formation }\end{array}$ \\
\hline 8 & $65 / F$ & $\begin{array}{l}\text { Smith Peterson nail L } \\
\text { femur fracture } \\
\text { (stainless steel) }\end{array}$ & Osteosarcoma & 9 years & $\begin{array}{l}\text { Pain, nail removed, continued } \\
\text { pain, THR for "osteoarthritis" }\end{array}$ \\
\hline 9 & $38 / \mathrm{M}$ & $\begin{array}{l}\text { Vesely-Street nail L } \\
\text { femur fracture } \\
\text { (stainless steel) }\end{array}$ & Osteosarcoma & 20 years & $\begin{array}{l}\text { Severe pain, permeative bone } \\
\text { changes with calcification at } \\
\text { nail tip }\end{array}$ \\
\hline 10 & $68 / \mathrm{M}$ & $\begin{array}{l}\text { B THR for OA (titanium } \\
\text { alloy) }\end{array}$ & Osteosarcoma & 3 years & $\begin{array}{l}\text { Pain, stiffness, swelling for } 3 \\
\text { months, osteoblastic lesion }\end{array}$ \\
\hline 11 & $56 / \mathrm{M}$ & $\begin{array}{l}\text { Sampson nail R femur } \\
\text { fracture (stainless } \\
\text { steel) }\end{array}$ & Osteosarcoma & 15 years & $\begin{array}{l}\text { Pain, lytic lesion distal to old } \\
\text { fracture }\end{array}$ \\
\hline 12 & $61 / \mathrm{M}$ & $\begin{array}{l}\text { L THR for OA } \\
\text { (chromium and cobalt) }\end{array}$ & $\mathrm{MFH}$ & 6.5 years & Unknown \\
\hline
\end{tabular}

THR, total hip replacement; OA, osteoarthritis; MFH, malignant fibrous histiocytoma; MPNST, malignant peripheral nerve sheath tumor.

formed on Case 4, and immunohistochemistry was performed on Cases 4 and 6. Follow-up information was obtained from the patient charts or from the referring physicians. Five of the cases were previously reported $(20,21,23,34)$.

\section{RESULTS}

(Table 1.) The patient's ages ranged from 18 to 85 (mean 55) years at the time of diagnosis of the malignancy. Three patients were female, and nine were male. All tumors were associated with implants in the femur; eight in the proximal femur and four in the distal femur. Five patients had undergone total hip arthroplasty for osteoarthritis, four had intramedullary nail placement for fracture fixation (three in the proximal femur and one midshaft), one had staples placed after osteotomy for a genu valgum deformity, one had staples placed for an unknown reason, and one had hardware placed for fracture fixation followed 33 years later by a total hip arthroplasty on the same femur. The time interval between hardware placement and sarcoma detection was known in 11 cases and ranged from 2.5 to 33 (mean 11) years. The presenting symptoms were pain, stiffness and swelling. Ten sarcomas arose within the bone, and two in the adjacent soft tissue. Radiographically the tumors were located immediately adjacent to or surrounding the implant (Fig. 1) and demonstrated permeative de-

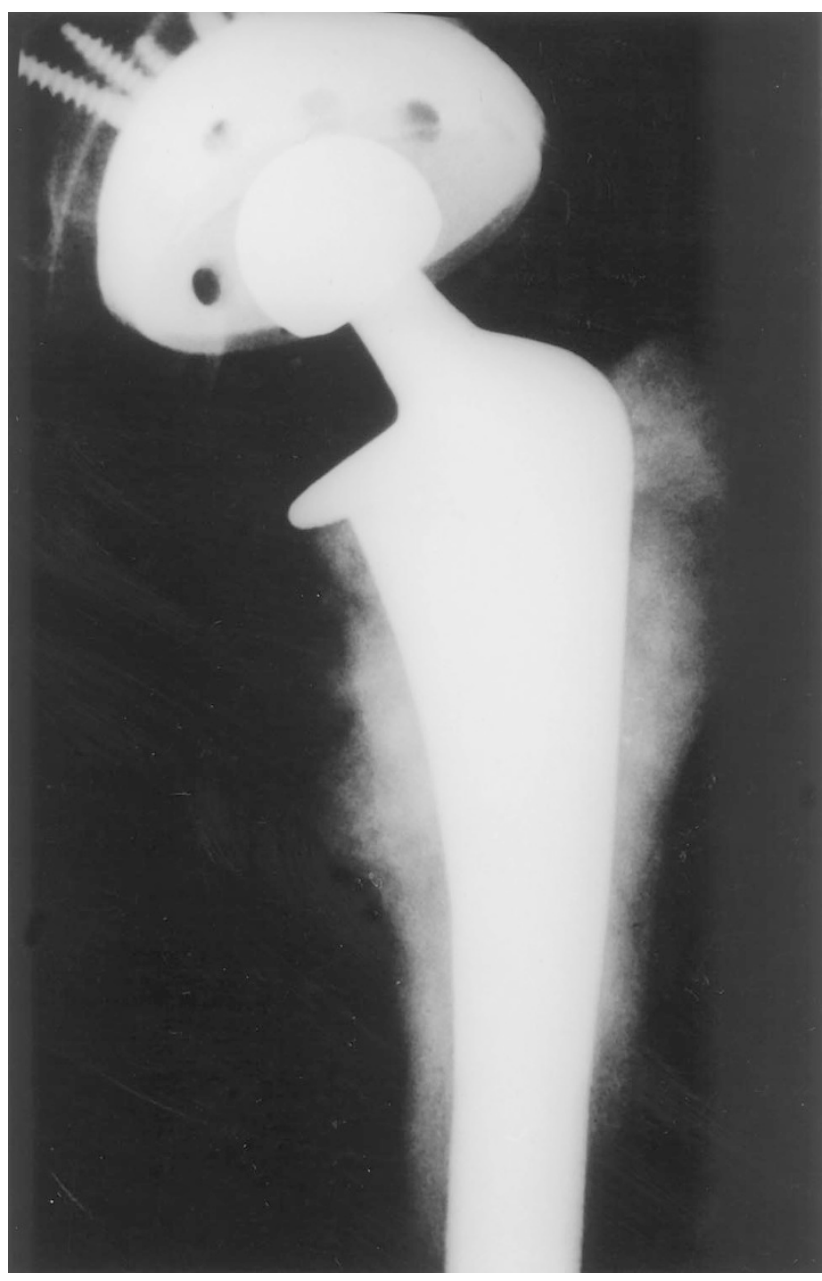

FIGURE 1. Radiograph demonstrating the blastic component of an osteosarcoma that surrounds the implant in Case 10. 
struction of the adjacent bone. Four sarcomas demonstrated obvious neoplastic matrix production.

In five patients the initial symptoms of the tumors were attributed to the pre-existing orthopaedic problem, which may have delayed the diagnosis (cases 2, 3, 8 to 10). In Case 2, an 18-year-old man who had a long history of Morquio's syndrome and related orthopaedic deformities recently developed pain but did not seek medical assistance for 2 months, at which time a large mass had become palpable. The patient in Case 3 sought medical advice because of pain and a biopsy was interpreted as infection. The biopsy was repeated one month later because of persistent pain and swelling, and the diagnosis of infection was again rendered. Four months later, when the mass was $25 \mathrm{~cm}$ in greatest diameter, the patient was rebiopsied and the diagnosis of inflammatory malignant fibrous histiocytoma was given. The patient in Case 8 had pain at the site of an intramedullary nail. An X-ray was interpreted as negative. After the pain persisted, the nail was removed, but the pain did not subside. A total hip replacement was performed several weeks later because the pain was thought to be secondary to osteoarthritis. Sarcoma was noted at the time of surgery. The young man in Case 9 experienced pain in the leg, which contained an intramedullary nail. An X-ray disclosed calcifications at the nail tip, but was thought to be otherwise normal. A lumbar disk was implicated as the cause of continued pain, and the patient underwent laminectomy. Because of persistent pain, the nail was finally removed at a later date, which led to perfuse bleeding because of an underlying telangiectatic osteosarcoma. In Case 10 the patient waited 3 months before seeking medical attention, at which time a large mass was noted on X-ray. After 4 weeks of pain, the patient in Case 4 sought medical attention at which time a large soft tissue mass was discovered. The remaining three patients in which clinical information is known sought medical assistance soon after the onset of pain. Radiographic studies in Cases 1, 7, and 11 obtained at that time of presentation demonstrated destructive bone lesions (Fig. 3).

\section{Pathology}

(Table 2.) All sarcomas arose in close proximity to the implant (Fig. 3), 10 in bone and 2 in soft tissue, and all were high grade. Seven tumors were osteosarcoma, four malignant fibrous histiocytoma (MFH) and one a malignant peripheral nerve sheath tumor. The size of the tumors ranged from 5 to 25 (mean 11) $\mathrm{cm}$ in greatest dimension and they varied from tan-grey to tan-yellow, and usually had areas of hemorrhage and necrosis (Figs. 4 and 5). Seven tumors were centered within bone and dem-

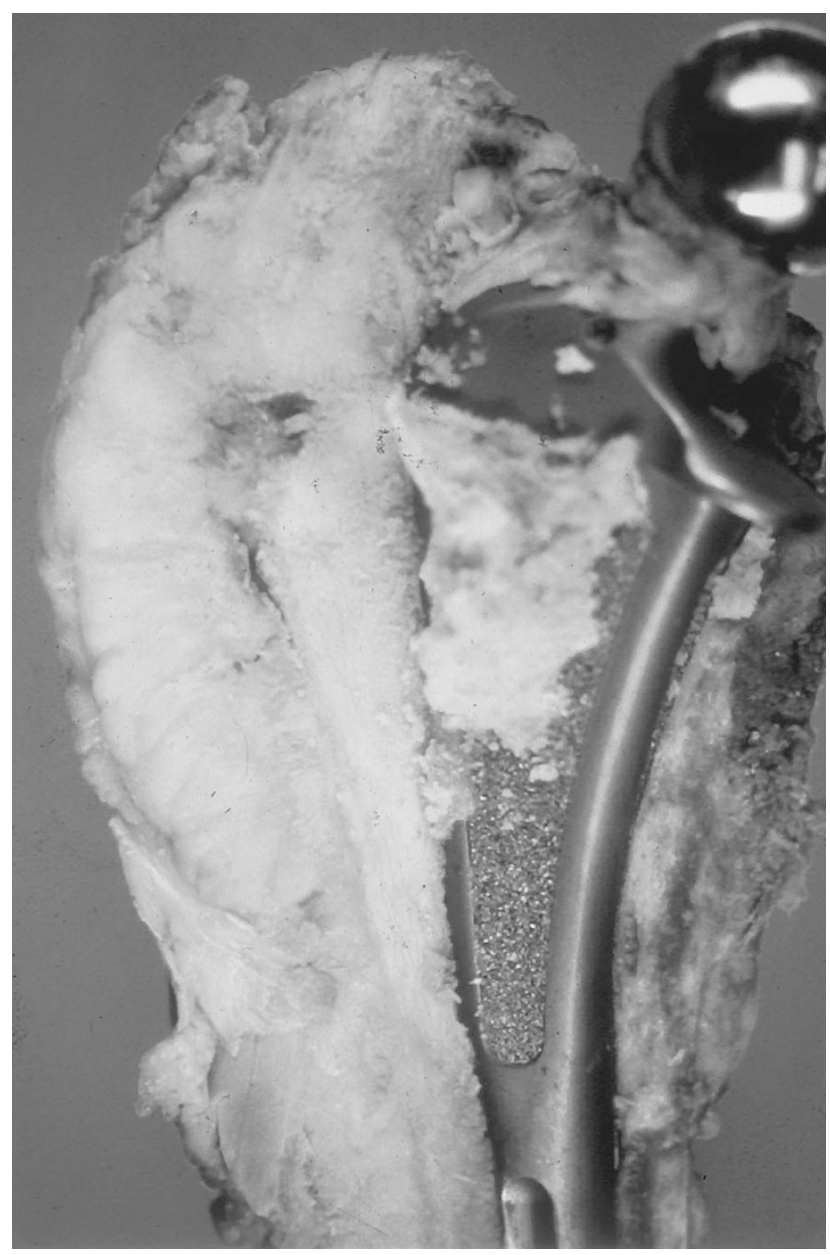

FIGURE 2. A large, tan osteosarcoma is adjacent to the implant in Case 10.

onstrated bone formation by malignant cells. Histopathologically, five of these were osteoblastic osteosarcomas (Fig. 6), displaying plump atypical cells with a high nuclear to cytoplasm ratio and abundant mitotic activity. Prominent in one of these tumors were areas where the malignant cells were spindled and formed fascicles arranged in a storiform pattern (Fig. 7) (mixed osteoblastic and malignant fibrous histiocytoma-like osteosarcoma). Another osteosarcoma displayed large areas of high-grade malignant cartilage admixed with neoplastic bone (Fig. 8) (mixed osteoblastic and chondroblastic osteosarcoma). Lastly, one osteosarcoma was extensively cystic, with multiple blood-filled cavities (Fig. 9). The cyst walls contained malignant cells with hyperchromatic, enlarged nuclei, which produced osteoid (telangiectatic osteosarcoma).

Of the four cases of MFH, three were the storiform-pleomorphic type and were located within bone. They were composed of severely atypical and bizarre spindle cells that were arranged in a storiform pattern (Fig. 10). Mitoses were numerous. The remaining MFH (Case 3) originated within the soft tissue adjacent to a hip prosthesis and was 
TABLE 2. Pathologic Findings in Patients with Implant-Related Sarcoma

\begin{tabular}{|c|c|c|c|c|}
\hline Case & Location & Diagnosis & Gross Description & Follow-Up \\
\hline 1 & $\mathrm{R}$ proximal femur & $\begin{array}{l}\text { Osteosarcoma, osteoblastic } \\
\text { and MFH-like types, } \\
\text { grade } 3 / 3\end{array}$ & $8 \times 7 \mathrm{~cm}$, tan-grey & $\begin{array}{l}\text { Pulmonary mets, debulking, chemo, } \\
\text { XRT, met to pubis, DOD } 1 \text { year }\end{array}$ \\
\hline 2 & $\mathrm{R}$ distal femur & $\begin{array}{l}\text { Osteosarcoma, osteoblastic } \\
\text { type, grade } 3 / 3\end{array}$ & $\begin{array}{l}9 \mathrm{~cm} \text {, tan, focally } \\
\text { hemorrhagic, path } \\
\text { fracture }\end{array}$ & $\begin{array}{l}\text { h/o Morquio's syndrome, chemo, } \\
\text { resection, LTF }\end{array}$ \\
\hline 3 & $\mathrm{R}$ proximal thigh & $\begin{array}{l}\text { MFH, inflammatory type, } \\
\text { grade } 2 / 3\end{array}$ & $\begin{array}{l}25 \times 25 \times 15 \mathrm{~cm}, \text { tan- } \\
\text { green and yellow }\end{array}$ & External hemipelvectomy, LTF \\
\hline 4 & L proximal thigh & MPNST, grade $3 / 3$ & $\begin{array}{l}10 \mathrm{~cm} \text {, tan-yellow, } \\
\text { focally hemorrhagic, } \\
\text { firm }\end{array}$ & XRT, resection, DWOD 2.5 years \\
\hline 5 & $\mathrm{R}$ distal femur & $\begin{array}{l}\text { Osteosarcoma, } \\
\text { chondroblastic type, } \\
\text { grade } 3 / 3\end{array}$ & $\begin{array}{l}13 \times 9 \times 7 \mathrm{~cm} \text {, pink } \\
\text { and yellow, hard }\end{array}$ & Above the knee amputation, LTF \\
\hline 6 & $\mathrm{R}$ proximal femur & $\mathrm{MFH}$, grade $2-3 / 3$ & $5.5 \mathrm{~cm}$ & XRT, resection. Died 7 mo \\
\hline 7 & L distal femur & MFH, high grade & Unknown & LTF \\
\hline 8 & $\mathrm{~L}$ proximal femur & $\begin{array}{l}\text { Osteoblastic osteosarcoma, } \\
\text { high-grade }\end{array}$ & $\begin{array}{l}5 \mathrm{~cm} \text { tan, } \\
\text { hemorrhagic, firm }\end{array}$ & $\begin{array}{l}\text { XRT, chemo, resection, mets DOD } 8 \\
\text { years }\end{array}$ \\
\hline 9 & L proximal femur & $\begin{array}{l}\text { Telangiectatic } \\
\text { osteosarcoma, high-grade }\end{array}$ & $10 \mathrm{~cm}$ & $\begin{array}{l}\text { Pulmonary mets, XRT, embolization, } \\
\text { DOD } 2 \text { months }\end{array}$ \\
\hline 10 & L proximal femur & Osteosarcoma, high-grade & $15 \times 8 \mathrm{~cm}$ & $\begin{array}{l}\text { Pulmonary mets, hemipelvectomy, } \\
\text { DOD } 6 \text { months }\end{array}$ \\
\hline 11 & $\mathrm{R}$ distal femur & $\begin{array}{l}\text { Osteoblastic osteosarcoma, } \\
\text { high-grade }\end{array}$ & $7 \mathrm{~cm}$ & Hip disarticulation, alive 6 years \\
\hline 12 & L proximal femur & $\mathrm{MFH}$, grade $3 / 3$ & Unknown & Hip disarticulation, DOD 1 year \\
\hline
\end{tabular}

THR, total hip replacement; OA, osteoarthritis; MFH, malignant fibrous histiocytoma; MPNST, malignant peripheral nerve sheath tumor; DOD, dead of disease; DWOD, dead without disease; mets, metastases; LTF, lost to follow-up; XRT, radiation therapy.

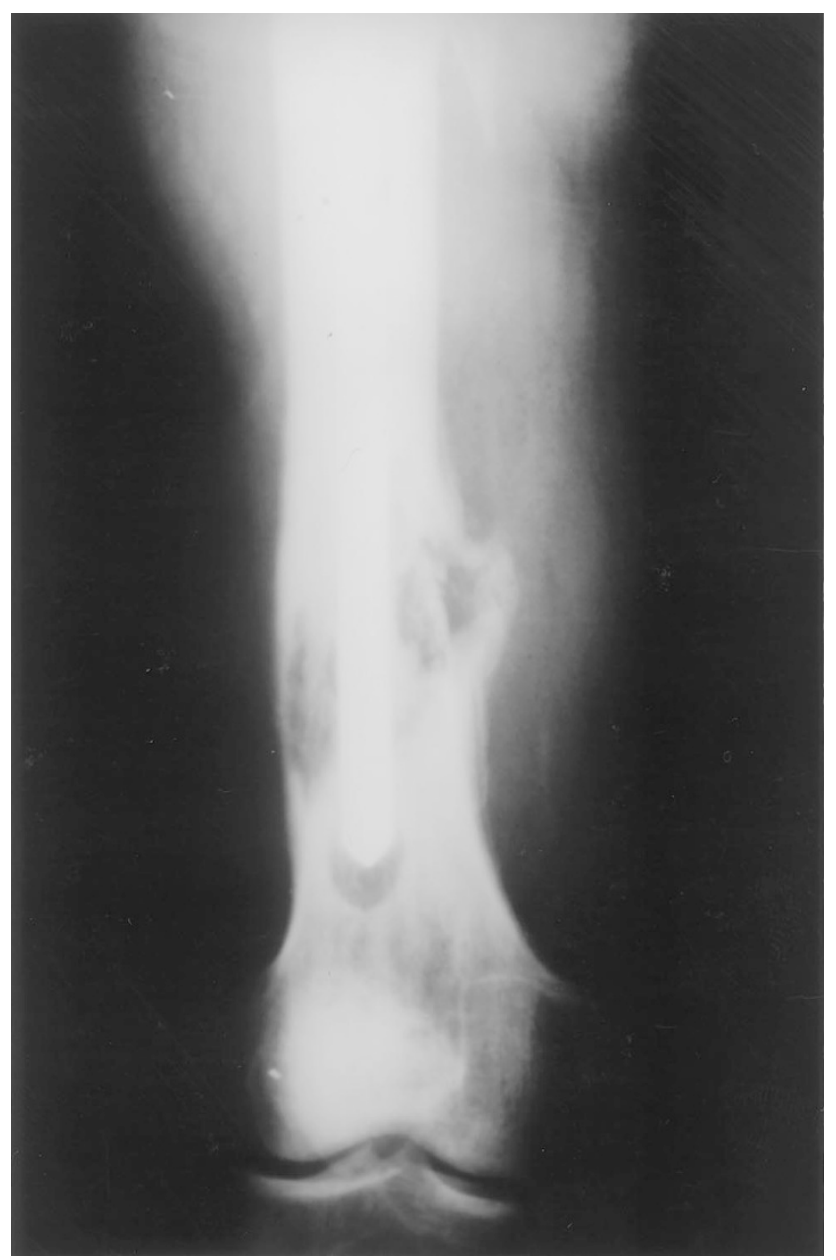

FIGURE 3. A destructive, lytic malignant fibrous histiocytoma surrounds the intramedullary nail in Case 7.

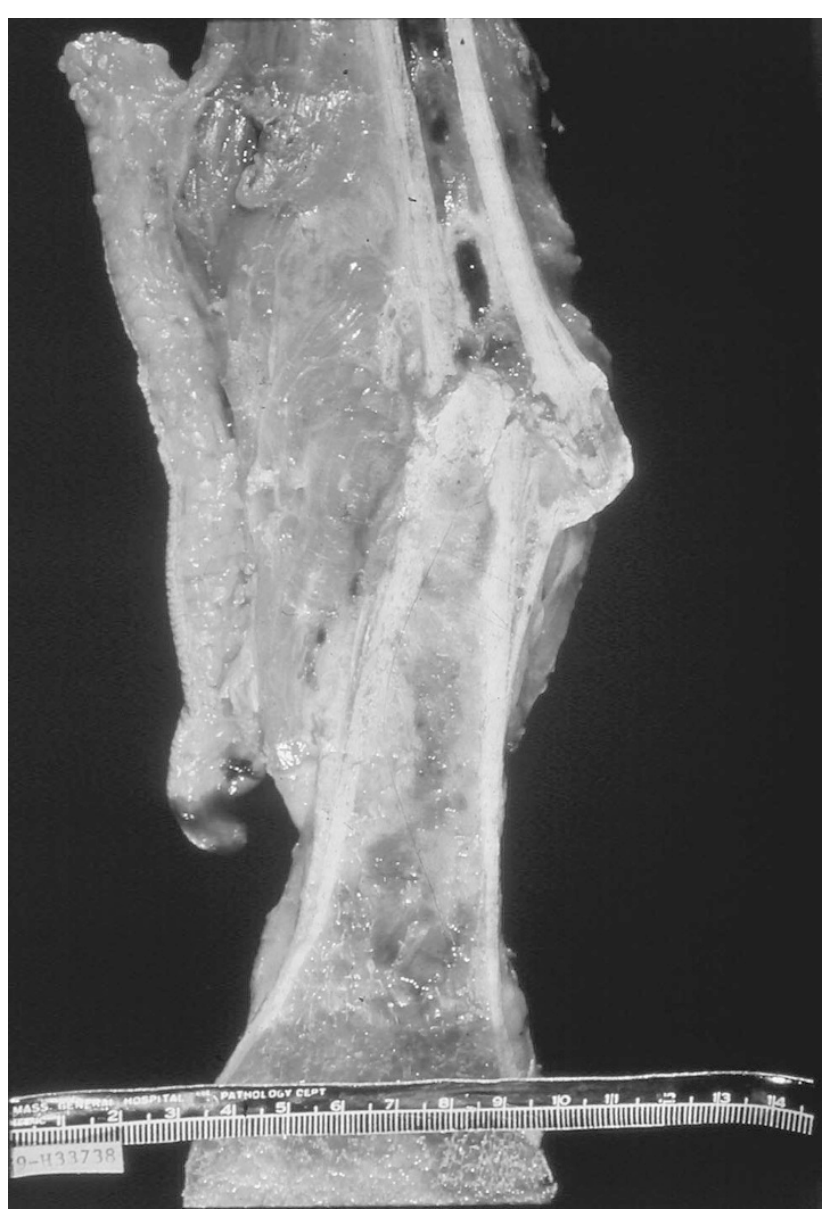

FIGURE 4. A pathologic fracture is present through the tan and red, focally cystic osteosarcoma in Case 2. 


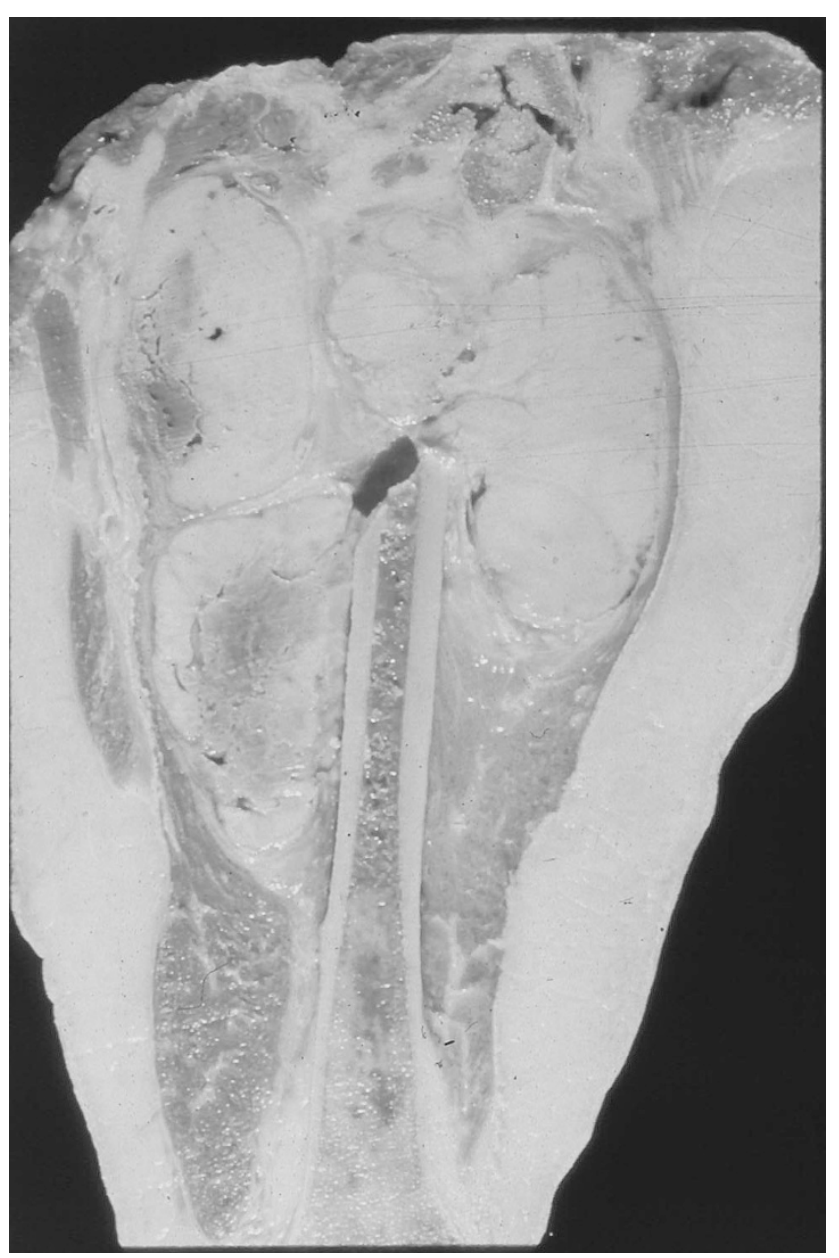

FIGURE 5. Areas of hemorrhage are present within the tan, fleshy malignant fibrous histiocytoma, which surrounds the femur in Case 3.

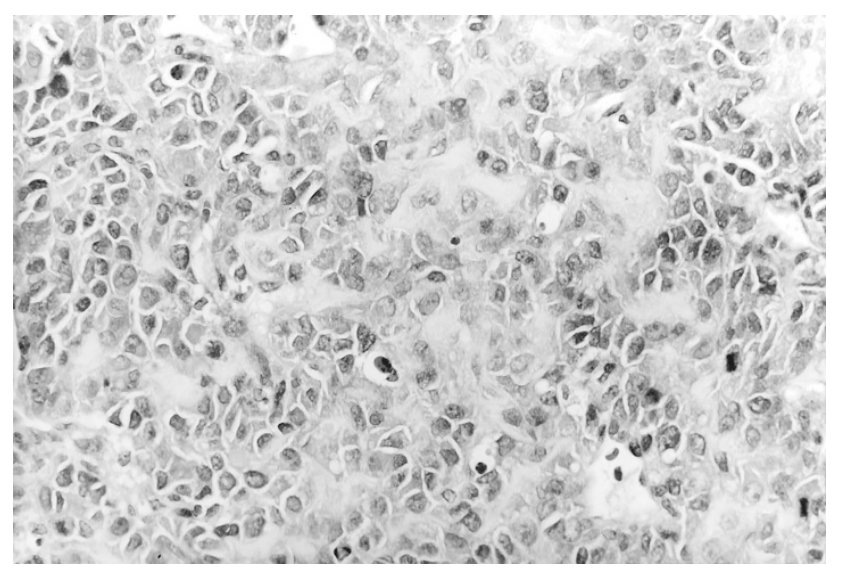

FIGURE 6. Plump tumor cells demonstrate osteoid production in Case 9.

composed of atypical epithelioid and spindle shaped cells that were infiltrated by numerous inflammatory cells including eosinophils, neutrophils and lymphocytes and was considered to be an inflammatory MFH (Fig. 11). Immunohistochemistry performed on formalin-fixed paraffinembedded tissue showed that the tumor cells in

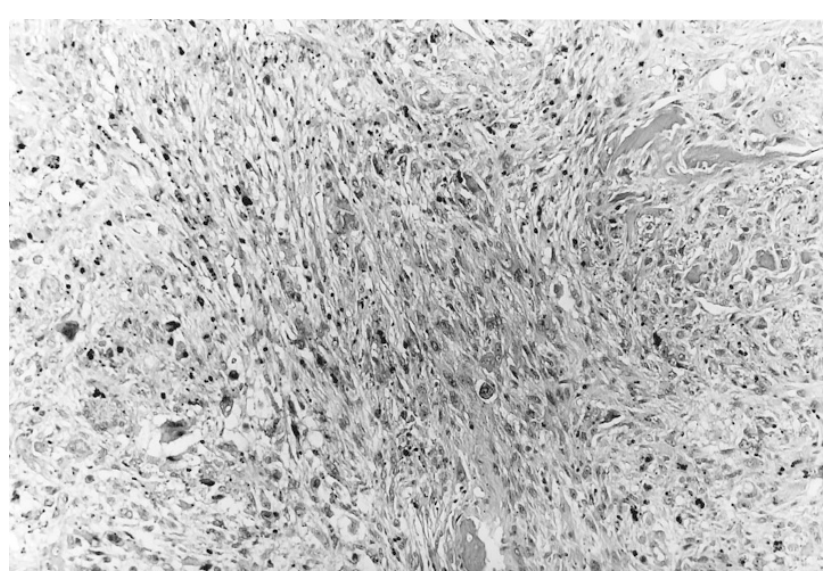

FIGURE 7. Osteosarcoma, which has a focally fascicular growth pattern (Case 1).

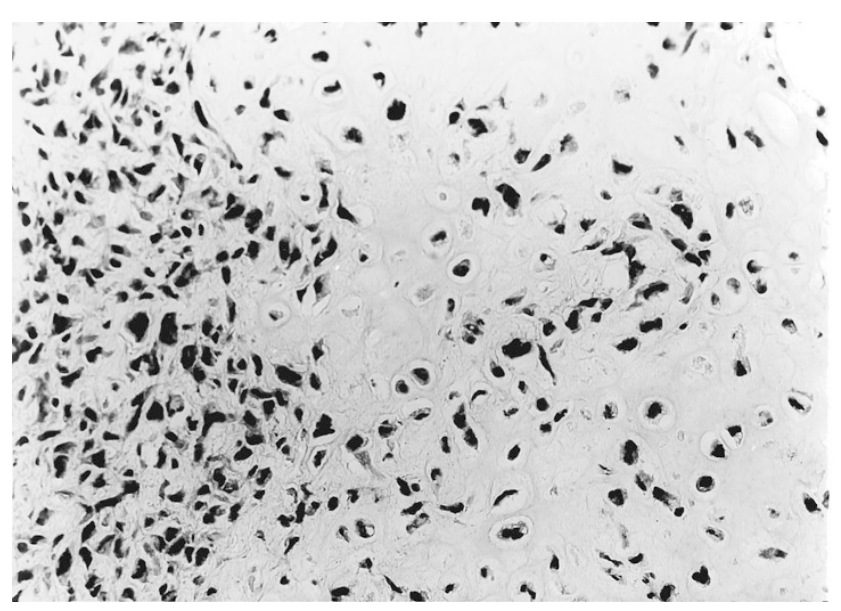

FIGURE 8. The osteosarcoma in Case 5 has areas of neoplastic cartilage formation.

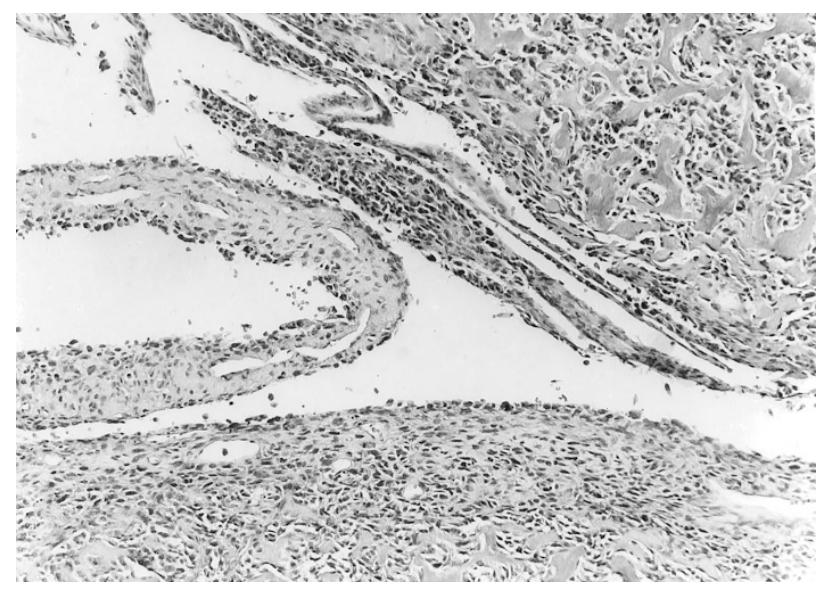

FIGURE 9. Cystic, spaces are characteristic of the telangiectatic osteosarcoma in Case 2.

Case 6 expressed vimentin, actin, smooth muscle actin, alpha-1-antichymotrypsin, and alpha-1antitrypsin. They did not express desmin or S-100 protein. This staining pattern supports the histologic impression of MFH with myofibroblastic 


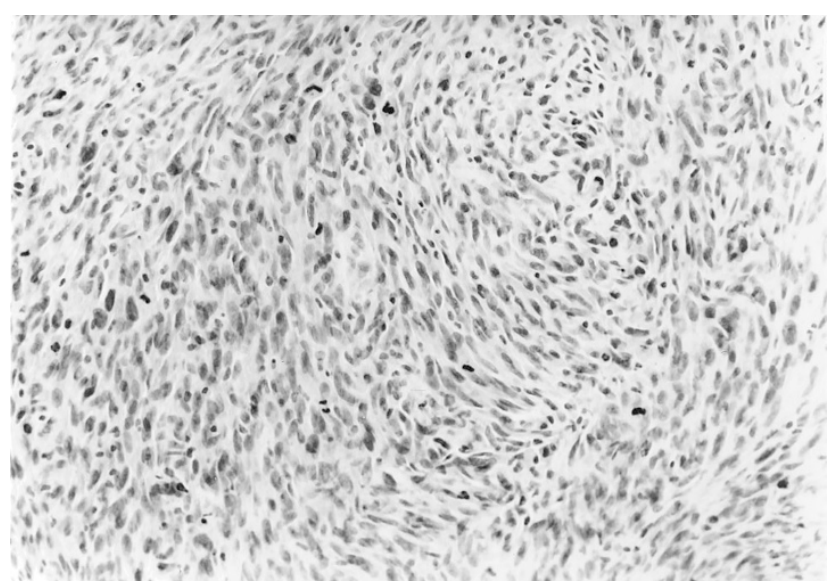

FIGURE 10. Whorling arrangement of spindle cells in a malignant fibrous histiocytoma (Case 12).

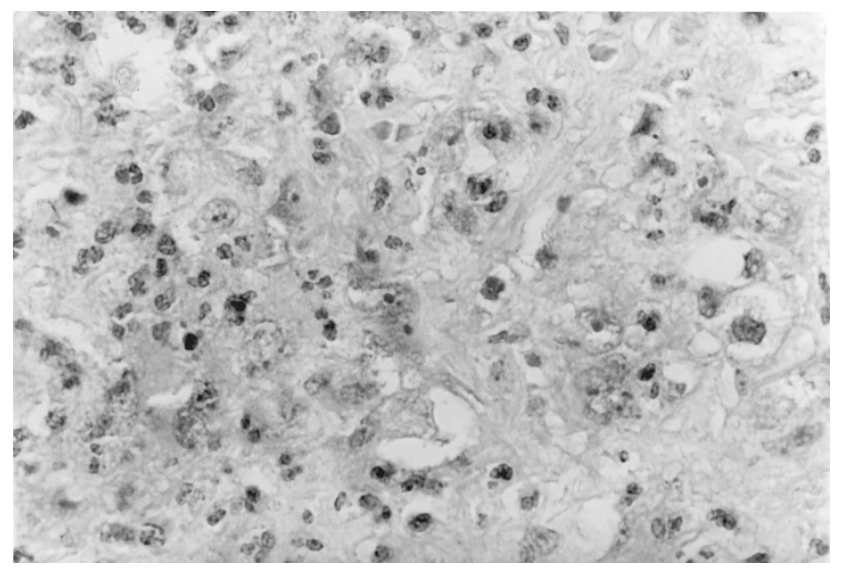

FIGURE 11. Acute and chronic inflammatory cells virtually obscure the malignant component of the inflammatory malignant fibrous histiocytoma (Case 3).

features. Immunohistochemistry was not performed on the other cases of MFH.

The malignant peripheral nerve sheath tumor (MPNST) was composed of large, spindle and focally epithelioid cells that had eosinophilic cytoplasm (Fig. 12) and were arranged in small swirls around vessels or other tumor cells. Multinucleate tumor cells were scattered throughout the mass. Mitotic activity was high, with many atypical forms and there was focal necrosis. Immunohistochemistry performed on formalin-fixed, paraffin-embedded tissue showed that the tumor cells expressed vimentin, alpha-1-antitrypsin, alpha-1-antichymotrypsin, and were focally positive for keratin. The tumor cells did not stain for desmin, smooth muscle actin, leu-7, S-100, or KP-1. Ultrastructural analysis revealed long, intertwining cell processes, intracellular junctions, and basal lamina, diagnostic of Schwann cell differentiation.

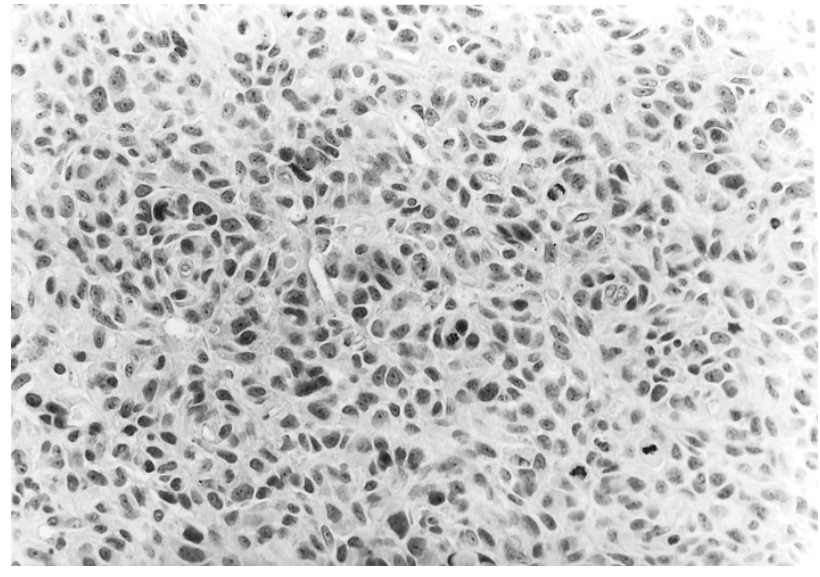

FIGURE 12. This malignant peripheral nerve sheath tumor is composed of epithelioid cells with a high mitotic rate (Case 4).

\section{Treatment and Follow-Up}

Three patients had pulmonary metastases at the time of diagnosis. The surgical treatment is known for 11 patients. Nine patients underwent wide resection of their tumor, and usually received adjuvant chemotherapy and/or radiation therapy (see Table 2). One patient had surgical debulking combined with radiation therapy and chemotherapy, and the patient with the telangiectatic osteosarcoma refused surgery and had radiation therapy and embolization of the tumor. Follow-up information is available on eight patients. Five patients died of disease 2 months to 8 years (mean 26 months) after diagnosis. Two patients died without evidence of disease 7 and 30 months after diagnosis. One patient is alive without disease 6 years after diagnosis.

\section{DISCUSSION}

The use of orthopaedic hardware and prosthetic joints has greatly advanced the treatment of skeletal diseases. Although the materials composing these implants are relatively biologically inert they may induce a variety of tissue responses (40). By far the most serious complication of orthopaedic hardware and prosthetic material is malignancy. Animal studies analyzing the biological effects of the components of prosthetic joints revealed carcinogenic properties of beryllium, cadmium, chromium, cobalt, iron, lead, nickel, selenium, zinc, and titanium $(2-4,7,41)$. In humans, prostheses containing cobalt, chromium, stainless steel, nickel, iron, manganese and silicon have been implicated as being carcinogenic. Other authors state that the placement of an implant may induce osteonecrosis, which in itself is a risk factor for the development of a sarcoma $(37,42)$. To date only 31 cases of implant-related sarcoma have been reported in the literature since the 1950s (Table 3) (9-37). This 


\begin{tabular}{|c|c|c|c|c|c|}
\hline Reference & Age/Sex & Diagnosis & Site & $\begin{array}{l}\text { Time } \\
\text { Interval }\end{array}$ & Hardware \\
\hline Arden et al. & 58/NA & FSA & Femur & 3 years & THR \\
\hline Bago-Granell et al. & $79 / \mathrm{F}$ & MFH & Femur & 2 years & THR \\
\hline Brien et al. & $69 / F$ & OSA & Femur & 8 years & THR \\
\hline Cole et al. & $63 / F$ & MFH & Femur & 2 years & THR \\
\hline Delgado et al. & $40 / \mathrm{M}$ & OSA & Tibia & 3 years & Plate \\
\hline Dube et al. & $84 / \mathrm{M}$ & Angiosarcoma & Tibia & 26 years & Plate \\
\hline Haag et al. & $78 / \mathrm{F}$ & MFH & Femur & 9 years & THR \\
\hline Harris et al. & $70 / \mathrm{F}$ & CSA & Femur & 3 years & THR \\
\hline Himmer et al. & $87 / F$ & Angiosarcoma & Femur & 1.7 years & TKR \\
\hline Hughes et al. & $42 / \mathrm{M}$ & MFH & Femur & 30 years & Plate \\
\hline Jacobs et al. & $65 / \mathrm{M}$ & MFH & Femur & 0.5 years & THR \\
\hline Lamovec et al. & $62 / \mathrm{M}$ & Synovial sarcoma & Femur & 12 years & THR \\
\hline Lamovec et al. & $65 / F$ & OSA & Acetabulum & 10 years & THR \\
\hline Lee et al. & $58 / \mathrm{M}$ & MFH & Femur & 14 years & Plate \\
\hline Martin et al. & $76 / F$ & OSA & Femur & 10 years & THR \\
\hline McDougal et al. & $42 / \mathrm{M}$ & Ewing's & Humerus & 30 years & Plate \\
\hline Nelson et al. & $72 / \mathrm{F}$ & MFH & Femur & 11 years & THR \\
\hline Penman et al. & $80 / F$ & OSA & Femur & 5 years & THR \\
\hline Ryu et al. & $52 / \mathrm{M}$ & Sarcoma & Acetabulum & 1.25 years & THR \\
\hline Swann et al. & $67 / \mathrm{M}$ & MFH & Femur & 4 years & THR \\
\hline Tait et al. & $56 / \mathrm{F}$ & MFH & Femur & 11 years & THR \\
\hline Tayton et al. & $11 / \mathrm{F}$ & Ewing's & Femur & 7.5 years & Plate \\
\hline Troop et al. & $54 / \mathrm{M}$ & MFH & Femur & 10 years & THR \\
\hline van der List et al. & $84 / \mathrm{F}$ & $\begin{array}{l}\text { Epithelioid } \\
\text { hemangioendothelioma }\end{array}$ & Femur/acetabulum & $\begin{array}{l}12 \text { years } / 0.5 \\
\text { years }\end{array}$ & THR \\
\hline Vives et al. & $70 / \mathrm{M}$ & $\mathrm{MFH}$ & Femur & 1.75 years & THR \\
\hline Weber et al. & $81 / \mathrm{F}$ & Epithelioid sarcoma & Tibia & 4.5 years & TKR \\
\hline
\end{tabular}

MFH, malignant fibrous histiocytoma; OSA, osteosarcoma; THR, total hip replacement; TKR, total knee replacement.

number is minuscule when compared with the 270,000 hip surgeries in addition to the hundreds of thousands of other hardware-related procedures performed in the U.S each year (1). Furthermore, a Finnish study of 31,651 patients who received polyethylene and metal hip prosthesis reported no associated sarcomas (43). However, the fact that malignancies have arisen in close proximity to metallic implants is strong evidence that there may be an important relationship. Chromosomal aberrations have been reported in the marrow adjacent to hip arthroplasties (44). In other anatomic sites, such as the lung, metal foreign bodies have also been associated with the development of malignancy (45).

An animal model for the development of sarcomas in rats that have been implanted with various biomaterials has shown that up to $67 \%$ of implant sites developed either a sarcoma or a reaction that they termed "proliferative, probably preneoplastic" (5). There was no correlation between the morphology of the sarcoma and the type of biomaterial that was implanted. The materials most often associated with these histologic changes were polymethylmethacrylate $(67 \%$ of sites), polyethylene $(59 \%$ of sites), silicone ( $56 \%$ of sites), and aliphatic polyurethane (52\% of sites). Pure titanium, nickel chromium, cobalt-chromium alloy and aluminum oxide were less often associated with proliferative and malignant changes. Preneoplastic mesenchymal lesions have not been well defined or classified and its exact meaning in this study is unclear.
The majority of our cases of implant-related sarcomas were osteosarcoma, followed by MFH, and a single case of MPNST. Combined with the cases reported in the literature previously, 15 are MFH, 12 osteosarcoma, 2 angiosarcoma, 2 Ewing's sarcoma, 1 each of fibrosarcoma, MPNST, epithelioid sarcoma, synovial sarcoma, epithelioid hemangioendothelioma, chondrosarcoma in a patient with Maffucci's syndrome, and an unclassified sarcoma. The age range of all patients who developed implant-related sarcomas is 11 to 87 (mean 50) years, which is similar to the age range in our series. The time interval from the insertion of the implant to the development of malignancy has ranged from 6 months to 30 years (mean 9) years, which is also similar to our results. Thirty-one sarcomas occurred in the femur, three in the tibia, two in the acetabulum, one in the humerus, and one involved both the femur and acetabulum. The propensity of the sarcomas to arise in the femur is probably related to the fact that it is the most common bone to be treated with an orthopaedic implant.

Large, high-grade sarcomas arising in bone or soft tissue have a poor prognosis. When coupled with a delay in the diagnosis of malignancy, prosthetic-related sarcomas have a high mortality. Follow-up information available on 14 of the 26 implant-related sarcomas reported in the literature demonstrates this point; one patient was free of disease 15 months after surgical therapy, 5 patients were dead 1 year after diagnosis, and 8 patients 
were dead less than 1 year after diagnosis. At least 8 of the 13 patients that died had metastatic disease at the time of death. The clinical outcome of our cases is similar. Of the eight patients with follow-up information, seven died of disease a mean of 26 months after diagnosis, and only one patient is alive and disease free. Clinically it may be difficult to detect an implant associated malignancy as implant-related symptoms caused by other processes are more common and radiographic imaging studies are compromised by the artifact induced by the metal component of the implant. Although the possibility of a sarcoma developing in association with an implant is extremely small, physicians should at least consider this possibility when pain or other new findings develop in relation to metallic orthopaedic hardware.

\section{REFERENCES}

1. Mushinski M. Average charges for hip replacement surgeries: United States, 1997. Stat Bull Metrop Insur Co 1999;80:3240.

2. Heath JC, Daniel MR. The production of malignant tumors by cadmium in the rat. Br J Cancer 1964;18:124-9.

3. Heath JC, Daniel MR. The production of malignant tumors by nickel in the rat. Br J Cancer 1964;28:261-4.

4. Heath JC, Freeman MAR, Swanson SAV. Carcinogenic properties of wear particles from prostheses made in cobaltchromium alloy. Lancet 1971;1:564-6.

5. Kirkpatrick CJ, Alves A, Kohler H, Kriegsmann J, Bittinger F, Otto M, et al. Biomaterial induced sarcoma. A novel model to study preneoplastic change. Am J Pathol 2000;156:1455-67.

6. Memoli VA, Urban RM, Alroy J, Galante Jo. Malignant neoplasms associated with orthopedic implant materials in rats. J Orthop Res 1986;4:346-55.

7. Sunderman FW. Metal carcinogenesis in experimental animals. Food Cosmet toxical 1971;9:105-20.

8. Sinibaldi K, Rosen H, Liu S, De Angelis M. Tumors associated with metallic implants in animals. Clin Orthop 1976;118: 257-66.

9. Arden GP, Bywaters EGL. Tissue reaction. In: Arden GP, Ansell BM, editors. Surgical management of juvenile chronic polyarthritis. London: Academic Press; 1978: p. 269-70.

10. Bago-Granell J, Aguirre-Canyadell M, Nardi J, Tallada N. Malignant fibrous histiocytoma of bone at the site of a total hip arthroplasty. J Bone Joint Surg (Br) 1984;66-B:38-40.

11. Brien WW, Salvati EA, Healy JH, Bansal M, Ghelman B, Betts F. Osteogenic sarcoma arising in the area of a total hip replacement. J Bone Joint Surg 1990;72-A:1097-9.

12. Cole BJ, Schultz E, Smilari TF, Hajdu SI, Krauss ES. Malignant fibrous histiocytoma at the site of a total hip replacement: review of the literature and case report. Skeletal Radiol 1997;26:559-63.

13. Delgado ER. Sarcoma following a surgically treated fractured tibia. Clin Orthop 1958;12:315-8.

14. Dube VE, Fisher DE. Hemangioendothelioma of the leg following metallic fixation. Cancer 1972;30:1260-6.

15. Haag M, Adler CP. Malignant fibrous histiocytoma in association with hip replacement. J Bone Joint Surg (Br) 1989;71B:701.

16. Harris WR. Chondrosarcoma complicating total hip arthroplasty in Maffucci's syndrome. Clin Orthop 1990;260:212-4.

17. Himmer O, Lootvoet L, Deprez P, et al. Angiosarcome apres prothese totale de genou. A propos d'un cas. Rev Chir Orthop Reparatrice Appar Mot 1991;77:125-8.
18. Hughes AW, Cherokee DA, Hamblen DL, Reid R. Sarcoma at the site of a single hip screw. J Bone Joint Surg 1987;69-B: $470-2$.

19. Jacobs JJ, Rosenbaum DH, Hay RM, Gitelis S, Black J. Early sarcomatous degeneration near a cementless hip replacement. J Bone Joint Surg 1992;74B:740-4.

20. Jaffe KA, Morris SG, Lemons JE, Robinson LH. Sarcomas around implants: three cases and a review of the literature. Journal of the Southern Orthopaedic Association 1994;3:12734 .

21. Khurana JS, Rosenberg AE, Kattapuram SV, Fernandez OS, Ehara S. Malignancy supervening on an intramedullary nail. Clin Orthop 1991;267:251-4.

22. Lamovec J, Zidar A, Cucek-Plenicar M. Synovial sarcoma associated with total hip replacement. J Bone Joint Surg 1988;70-A:1558-60.

23. Lane JM, Rosenberg AE. Case records of the Massachusetts General Hospital (Case 4-1991). N Engl J Med 1991;324: 251-9.

24. Lee Y, Pho RW, Nather A. Malignant fibrous histiocytoma at site of metal implant. Cancer 1983;54:2286-9.

25. Martin A, Bauer TW, Manley MT, Marks KE. Osteosarcoma at the site of total hip replacement. J Bone Joint Surg 1988; 70-A:1561-7.

26. McDougall A. Malignant tumor at the site of bone plating. J Bone Joint Surg 1957;38B:709-13.

27. Nelson JP, Phillips PH. Malignant fibrous histiocytoma associated with total hip replacement. Orthopaedic Review 1990;19:1078-80.

28. Penman HG, Ring PA. Osteosarcoma in association with total hip replacement. J Bone Joint Surg (Br) 1984;66-B: 632-4.

29. Ryu RKN, Bovill EG, Skinner HB, Murray WR. Soft tissue sarcoma associated with aluminum oxide ceramic total hip arthroplasty. Clin Orthop 1987;216:207-12.

30. Swann M. Malignant soft tissue tumor at the site of a total hip replacement. J Bone Joint Surg 1984;66-B:629-31.

31. Tait NP, Hacking PM, Malcolm AJ. Malignant fibrous histiocytoma occurring at the site of previous total hip replacement. Br J Radiol 1988;61:73-6.

32. Tayton KJJ. Ewing's sarcoma at the site of a metal plate. Cancer 1980;45:413-5.

33. Troop JK, Mallory TH, Fisher DA, Vaughn BK. Malignant fibrous histiocytoma after total hip arthroplasty. Clin Orthop 1990;253:297-300.

34. van der List JJJ, van Horn JR, Sloof TJJH, ten Cate LN. Malignant epithelioid hemangioendothelioma at the site of a hip prosthesis. Acta Orthop Scand 1988;53:328-30.

35. Vives P, Sevestre H. Grodet H, et al. Histiocytome fibreux malin du femur apres prothes totale de hanche, a propos d'un cas. Rev Chir Orthop reparatrice Appar Mot 1987;73: 407-9.

36. Ward JJ, Thornbury DD, Lemons JE, Dunham WK. Metalinduced sarcoma. A case report and review of the literature. Clin Orthop 1990;252:299-306.

37. Weber PC. Epithelioid sarcoma in association with total knee replacement. J Bone Joint Surg 1986;68:824-6.

38. Dodion P, Putyz P, Amiri-Lamraski MH, Efira A, Martelaere E, Heimann R. Immunoblastic lymphoma at the site of an infected vitallium bone plate. Histopathology 1982;6:807-13.

39. McDonald I. Malignant lymphoma associated with internal fixation of a fractured tibia. Cancer 1981;48:1009-11.

40. Jacobs JJ, Skipor AK, Black J, Urban RM, Galante JO. Release and excretion of metal in patients who have a total hipreplacement component made of titanium-base alloy. J Bone Joint Surg 1991;73-A:1475-86.

41. Pedley RB, Meachim G, Williams DF. Tumor induction by implant materials. In: Williams DF, editor. Fundamental as- 
pects of biocompatibility. Vol. 2. Boca Raton, FL: CRC Press; 1981. p. 175.

42. Hamblen DL. Sarcoma and joint replacement [editorial]. J Bone Joint Surg 1984;66-B:625-7.

43. Paavolainen P, Pukkala E, Pulkkinen P, Visuri T. Cancer incidence in Finnish hip replacement patients from 1980 to 1995: a nationwide cohort study involving 31,651 patients. J Arthroplasty 1999;14:272-80.
44. Case CP, Langkamen G, Howell RT, Webb J, Standen G, Palmer M, et al. Preliminary observations on possible premalignant changes in bone marrow adjacent to worn total hip arthroplasty implants. Clin Orthop Relat Res 1996;329: S269-79.

45. Siddons AHM, MacArthur AM. Carcinomata developing at the site of foreign bodies in the lung. Br J Surg 1952;39: $542-5$.

\section{Book Review}

\section{Mattson MP, editor: Pathogenesis of Neurode- generative Disorders, 304 pp, Totowa, NJ, Humana Press, 2001 (\$135.00).}

This book is a timely collection of 12 papers authored by 26 experts from the USA, UK, Australia, and Switzerland. The first two chapters cover the basic molecular and biochemical mechanisms that seem to play a pivotal role in the various forms of neuronal degeneration. During “The Decade of Brain” (1990-2000), enormous amounts of new information have been accumulated about the various mechanisms that induce neuronal damage and death. As it is clearly summarized in the first two chapters, the basic processes that are relevant in this regard are apoptosis, neuronal excitotoxicity, and oxidative stress (i.e., freeradical-mediated damage). An understanding of these cellular or subcellular processes is essential because, although to variable degrees, they all play a role in the specific forms of disorders that in the not too distant past had been described almost purely on phenomenological level. It is now obvious that the above-mentioned mechanisms combined with specific molecular genetic and environmental factors are responsible for the development of the diseases that are covered in a concise, remarkably up-to-date manner in subsequent chapters. These include Parkinson's disease (PD), Huntington's disease (HD), Alzheimer's disease (AD), Down syndrome, ALS, ischemic stroke, spinal cord injury, and Duchenne Muscular Dystrophy. The chapter on "Trinucleotide Repeat Disorders" provides fascinating reading, and, although it focuses on one of these disorders (dentatorubral-pallidoluysian atrophy [DRPLA]), it is rather didactic because it is known that at least eight forms of hereditary neurodegenerative disorders are caused by expansion of CAG trinucleotide repeats.

The 12 chapters are balanced in length, are all well referenced, and provide a state of the art summary for those who are only tangentially involved in studying these disorders or treating patients suffering from any of them. On the other hand, for those whose main interest lies in research related to any of these diseases, it is a refreshing, well-written, and well-edited overview of a field that evolves and changes at unprecedented speed. Even when one is in the epicenter of scientific endeavors to unravel the heretofore unknown details of a specific disease, it is often very helpful to step back and take time to look at the "Big Picture." And this is exactly what the editor has achieved. With the help of well-known experts in the relevant fields, several basic pieces of the puzzle are provided that with the appropriate intellectual efforts can be sewn together. The result is the emergence of an overall view, the "Big Picture." The chapters on stroke and spinal cord injuries best exemplify this. At first glance it is not evident why circulatory disorders or trauma would fit the requirements for being included in the group of neurodegenerative diseases; even more so because many of the latter often are still viewed as system or multisystem abnormalities. It is time to realize that a disease with single, apparently distinct clinical phenotype can have several underlying causes. The other side of the coin is that the same neurodegenerative process may present as several clinical phenotypes. But the basic, fundamental changes are the ones outlined in Chapters 1 and 2. This realization redefines the concept of selective vulnerability. This series of papers definitely helps to make the necessary mental "switch" from older, phenomenological classifications to the emerging idea of common molecular pathomechanisms affecting selective parts of the CNS. The selectivity now is understood more as a combined effect of cellular biochemistry, molecular genetics, and the interaction of these variables with aging and environmental factors, many of the latter still being only partially clarified.

It is probably an inherent consequence of compiling individual articles and thus creating a book that the number of illustrations is rather low. Anyone engaged in writing papers for scientific journals is well aware of the restrictions that usually apply to the number of figures. This may explain why the individual chapters have only a few illustrations (including flow charts that would have been very helpful in many instances). However, the relative lack of illustrations is still one of the weaknesses of the book. Another that may be the result of the same cause is that the individual chapters are not structured the same way. Although each of them has an "Introduction" and "Conclusion," between these two basic structural elements the chapters are quite variably assembled. Regardless, the overall value of the book is undeniable, and it is beyond doubt that it will serve as a major reference source for neurologists, neuropathologists, and residents training in the respective fields.

\author{
Peter P. Molnar \\ University of Debrecen \\ Debrecen, Hungary
}

